\title{
HUBUNGAN FREKUENSI BABY SPA DENGAN PERKEMBANGAN PADA BAYI USIA 4-6 BULAN DI KLINIK BABY SPA AULIA
}

\author{
${ }^{1}$ Dwi Suprapti ${ }^{2}$ Neneng Sukmawati ${ }^{3}$ Rawat Umbarwati \\ ${ }^{1}$ STIKes Borneo Cendekia Medika Pangkalan Bun \\ ${ }^{1}$ Email : dwi.suprapti99@gmail.com
}

\begin{abstract}
ABSTRAK
Masa bayi adalah masa keemasan sekaligus masa krisis perkembangan. Prevalensi gangguan tumbuh kembang di Indonesia berdasarkan data Badan Pusat Statistik Kesehatan Bayi di Kalimantan Tengah pada tahun 2007, didapatkan bahwa gangguan perkembangan menempati prevalensi tertinggi setelah masalah gizi. Salah satu alternatif dalam memberikan rangsangan pada bayi untuk perkembangan adalah Baby spa yang dilakukan dengan dua cara, yaitu mandi berendam atau berenang dan pijat. Penelitian ini bertujuan untuk mengetahui hubungan frekuensi baby spa dengan perkembangan pada bayi usia 4-6 bulan di Klinik Baby Spa Aulia. Desain penelitian menggunakan penelitian deskriptif korelasi dengan pendekatan cross sectional. Sampel yang digunakan berjumlah 34 bayi usia 4-6 bulan di Klinik Baby Spa Aulia. Teknik sampling yang digunakan adalah purposive sampling. Analisis bivariat menggunakan uji Chi Square. Responden yang termasuk pada bayi usia 4-6 bulan yang melakukan baby spa pada kategori tidak rutin sebanyak 19 (55,9\%), kategori rutin sebanyak $15(44,1 \%)$ dan perkembangan bayi suspect sebanyak $12(35,3 \%)$, perkembangan normal sebanyak $22(64,7 \%)$. Hasilnya $p$ - value $=0,043<\alpha(0,05)$. Ada hubungan yang signifikan antara frekuensi baby spa dengan perkembangan bayi usia 4-6 bulan di Klinik Baby Spa Aulia. Diharapkan penelitian ini dapat menjadi salah satu alternatif dalam memberikan rangsangan perkembangan bayi.
\end{abstract}

\section{Kata Kunci : Frekuensi Baby Spa, Perkembangan}

\section{RELATIONSHIP OF BABY SPA FREQUENCY WITH DEVELOPMENT IN BABY AGES 4-6 MONTHS IN BABY SPA AULIA CLINIC}

\begin{abstract}
Infancy is a golden period as well as a period of developmental crisis. The prevalence of developmental disorders in Indonesia based on data from the Central Bureau of Health Statistics of Babies in Central Kalimantan in 2007, found that developmental disorders occupy the highest prevalence after nutritional problems. One alternative in providing stimulation to the baby for development is a baby spa which is done in two ways, namely bathing or swimming and massage. This study aims to determine the relationship of baby spa frequency with development in infants aged 4-6 months at the Aulia Baby Spa Clinic. The study design uses descriptive correlation research with cross sectional approach. The samples used were 34 infants aged 4-6 months at the Aulia Baby Spa Clinic. The sampling technique used was purposive sampling. Bivariate analysis using Chi Square test. Respondents included in infants aged 4-6 months who did the baby spa in the non-routine
\end{abstract}


category were 19 (55.9\%), the routine category were 15 (44.1\%) and the development of the suspect baby was 12 (35.3\%), normal development as many as 22 $(64.7 \%)$. The result is $p$-value $=0.043<\alpha(0.05)$. There is a significant relationship between the frequency of baby spas and the development of infants aged 4-6 months at the Aulia Baby Spa Clinic. It is hoped that this research can be an alternative in providing stimulation for infant development.

Keywords: Baby Spa Frequency, Development

\section{PENDAHULUAN}

Masa bayi adalah masa keemasan sekaligus masa krisis perkembangan seseorang. Dikatakan masa kritis karena pada masa ini bayi sangat peka terhadap lingkungan dan dikatakan masa keemasan karena masa bayi berlangsung sangat singkat dan tidak dapat di ulang kembali. Masa bayi dibagi menjadi dua periode yaitu masa neonatal dan masa post neonatal. Masa neonatal dimulai dari umur 0-28 hari, sedangkan masa post neonatal dimulai dari umur 29 hari sampai 11 bulan (Departemen Kesehatan, 2009). Bayi adalah individu yang lemah dan memerlukan proses adaptasi. Kesulitan proses adaptasi akan mengalami keterlambatan perkembangan, perilaku yang tidak teratur bahkan sampai meninggal dunia (Mansyur, 2009).

Menurut Kementrian Kesehatan RI (2011) jumlah bayi di Indonesia 4.372.600 jiwa. Sekitar $16 \%$ bayi di Indonesia mengalami gangguan perkembangan saraf dan otak mulai ringan sampai berat (Depkes, 2006). Prevalensi gangguan tumbuh kembang di Indonesia berdasarkan data Badan Pusat Statistik Kesehatan Bayi di kalimantan Tengah (2007), didapatkan bahwa gangguan perkembangan menempati prevalensi tertinggi setelah masalah gizi (>35\%), prevalensi diare yang terdeteksi (16,7\%). Data tersebut menggambarkan bahwa bayi dan beresiko tinggi terjadi masalah kesehatan. Setiap anak tidak akan melewati tahap perkembangan sebelum ia melewati tahapan sebelumnya sebagai contoh, seorang anak tidak akan bisa berjalan sebelum ia bisa berdiri. Seorang anak tidak akan bisa berdiri bila pertumbuhan kaki dan bagian tubuh lain yang terkait dengan fungsi berdiri anak terhambat, karena itu perkembangan awal merupakan masa kritis karena akan menentukan perkembangan selanjutnya. Menurut Pusponegoro (2006), setiap 2 dari 1000 bayi mengalami gangguan perkembangan, karenanya perlu kecepatan menegakkan diagnosis dan melakukan terapi untuk proses penyembuhannya.

Bayi yang mengalami keterlambatan dalam perkembangan akan membuat orangtua bayi merasa cemas dan khawatir sehingga mempengaruhi bagaimana orangtua memenuhi kebutuhan bayinya. Seperti ibu tidak mengajak berbicara dan ibu tidak melatih tangan dan kakinya secara teratur. Kurangnya rangsangan yang diberikan pada bayi akan memperparah keterlambatan pada bayi. Banyak riset menunjukkan bayi membutuhkan rangsangan dini berbagai bagian tubuh dan alat-alat indra untuk membantu bayi dalam 
penyesuaian diri terhadap lingkungan barunya.

Periode penting dalam tumbuh kembang anak adalah masa bayi dan balita. Pada masa bayi dan balita, perkembangan kemampuan berbahasa, kreativitas, kesadaran sosial, emosional, dan intelegensia berjalan sangat cepat dan merupakan landasan perkembangan berikutnya. Perkembangan anak terdapat masa kritis, sehingga diperlukan rangsangan atau stimulasi yang berguna agar potensi anak berkembang secara optimal. Anak yang mendapat stimulasi yang terarah dan teratur akan lebih cepat berkembang dibandingkan dengan anak yang kurang atau tidak mendapat stimulasi (Soetjiningsih, 2012).

Perkembangan pada anak mencakup perkembangan motorik halus, motorik kasar, bahasa, dan perkembangan adaptasi sosial. Motorik kasar adalah gerakan tubuh yang menggunakan otot-otot besar atau sebagian besar atau seluruh anggota tubuh. Contohnya kemampuan duduk, menendang, berlari, naik-turun tangga dan sebagainya. Sedangkan motorik halus adalah gerakan yang menggunakan otot-otot halus atau sebagian anggota tubuh tertentu, yang dipengaruhi oleh kesempatan untuk belajar dan berlatih (Mansyur, 2009). Perkembangan bahasa merupakan yang berhubungan dengan kemampuan untuk memberikan respon terhadap suara, mengikuti perintah, dan berbicara secara spontan. Sedangkan perkembangan adaptasi sosial merupakan yang berhubungan dengan kemampuan untuk mandiri, bersosialisasi, dan berinteraksi dengan lingkungan (Andriati dan Wirjatmadi, 2012).
Kurangnya rangsangan lingkungan pada anak dapat menyebabkan keterlambatan dan gangguan perkembangan pada anak. Oleh karena itu, anak perlu mendapatkan rangsangan sejak awal untuk perkembangannya (Riksani, 2014). Jumlah salon bagi bayi memang masih sedikit dijumpai. Umumnya salon hanya melayani pemotongan rambut saja. Padahal kebutuhan bayi semakin lama semakin meningkat, khususnya pada anak yang memiliki orangtua yang sibuk karena bekerja. Salah satu alternatif dalam pemenuhan kebutuhan bayi adalah spa. Perawatan spa tidak hanya dilakukan bagi orang dewasa saja, namun juga merambah ke usia bayi dan anak-anak. Perawatan ini sangat bermanfaat bagi kesehatan dan perkembangan sang bayi, dikarenakan semakin bertambahnya usia semakin bertambah pula aktifitas yang bermacam-macam (Yahya, 2011).

Memiliki anak yang sehat, bugar, ceria, dan sehat merupakan dambaan setiap orangtua. Salah satu cara yang sangat baik dalam mewujudkan itu adalah dengan cara spa pada bayi dan anak. Bayi dan anak yang telah diterapi dengan spa akan terlihat segar, sehat, bersemangat dan lebih cepat pertumbuhan perkembangannya dibandingkan bayi yang tidak pernah diberikan stimulasi rangsangan. Adapun ASTI (Asosiasi Spa Terapis Indonesia) menggunakan kata spa sebagai upaya untuk mencapai kesehatan jiwa-raga-sukma secara seimbang dengan menggunakan berbagai metode (Yahya, 2011).

Menurut Permenkes No. 1205/Menkes/X/2004, spa merupakan upaya tradisional yang menggunakan pendekatan holistic, melalui perawatan 
menyeluruh dengan menggunakan metode kombinasi antara hidroterapi (terapi air) dan massage (pijat) yang dilakukan secara terpadu untuk menyeimbangkan tubuh, pikiran, serta perasaan. Baby spa merupakan perawatan spa tubuh pada bayi yang dapat dilakukan dengan dua cara, yaitu mandi berendam atau berenang dan pijat. Manfaat dari baby spa adalah meningkatkan gerakan motorik anak, meningkatkan jumlah makanan yang diserap tubuh (termasuk ASI-air susu ibu), meningkatkan imunitas anak, dan masih banyak lagi manfaat lainnya.

Usia 4-6 bulan merupakan saat yang tepat bagi bayi untuk mengenal kolam renang. Hal ini dikarenakan reflek akuatiknya belum menghilang (kemampuan menarik nafas sebelum menyentuh air), bayi juga mempunyai naluri mengapung dan menyelam yang mencegahnya menelan air saat berada di dalam air. Renang bayi dilakukan menggunakan pelampung khusus dan dilakukan berkisar 10-15 menit, dua kali seminggu. Air yang digunakan untuk berenang cukup hangat, minimal bersuhu $34-35^{0} \mathrm{C}$ agar bayi tidak kedinginan dan rileks (Riksani, 2014).

Berendam dan berenang akan merangsang gerakan motorik bayi. Dengan bermain air, otot-otot bayi akan berkembang dengan sangat baik, persendian tumbuh secaa optimal, pertumbuhan badan meningkat, dan tubuh pun menjadi lentur. Dengan berenang gerakan didalam air semua anggota tubuh bayi akan terlatih, karena seluruh anggota tubuh digerakkan mulai dari kaki, tangan hingga kepala walaupun belum sempurna. Selain itu kemampuan mengontrol otot bayi akan lebih meningkat karena pada saat berenang didalam air efek gravitasi sangat rendah sehingga memungkinkan bayi untuk bergerak lebih banyak dan semua otot pun dapat bekerja dengan optimal. Pemijatan bayi lebih dini, bayi akan memperoleh manfaat lebih besar. Bayi yang di pijat akan terlihat lebih responsif, dapat lebih banyak menyapa dengan kontak mata, lebih banyak tersenyum, lebih banyak banyak bersuara, lebih banyak menanggapi, lebih cepat mempelajari lingkungan, dan lebih tanggap (Yahya,2011).

Klinik Baby Spa Aulia adalah satusatunya tempat baby spa yang ada di bamban, dengan semakin meningkatnya kesadaran untuk hidup sehat saat ini, masyarakat semakin peduli akan pentingnya perawatan tubuh secara menyeluruh, seperti perawatan kulit wajah, kulit tubuh, rambut dan kuku, tidak terkecuali pada bayi dan anak, maka dari itu minat untuk mengunjungi baby spa akan lebih meningkat. Pengunjung Klinik Baby Spa Aulia yang berada diwilayah pangkalan bun pada bulan Maret 2014 pengunjung Baby Spa Aulia sebanyak 51 bayi, pada bulan April 2014 pengunjung Baby Spa Aulia sebanyak 36 bayi, sedangkan pada bulan Mei 2014 pengunjung Baby Spa Aulia sebanyak 59 bayi. Sehingga dapat disimpulkan bahwa rata-rata pengunjung Klinik Baby Spa aulia memiliki banyak pengunjung yang datang untuk melakukan baby spa.

Berdasarkan wawancara yang telah dilakukan di Klinik Baby Spa Aulia pada 7 orangtua bayi ternyata $3(43 \%)$ orang ibu mengatakan setelah bayinya melakukan baby spa selama 2x dalam 1 minggu, perkembangan dan pertumbuhan bayinya menjadi lebih awal dan baik selain itu bayi lebih aktif, responsif dan tidak mengalami 
keterlambatan dalam proses tumbuh kembangnya. Bayi pada usia 4 bulan sudah bisa tengkurap dengan mengangkat kepala, melakukan gerakan dengan menekan kedua tangan, mampu memalingkan kepala ke kanan dan ke kiri, berguling dan terlentang ke tengkurap. Sedangkan pada $2(28,5 \%)$ orang ibu mengatakan tidur bayinya semakin lelap dan lebih lama karena tidak rewel. Bayi tidur pada malam dan siang hari kurang lebih 14-15 jam per hari, dan pada 2 $(28,5 \%)$ orang ibu mengatakan nafsu makan bayi semakin meningkat sehingga berat badan bayi semakin bertambah dan bayi terlihat sehat.

Sedangkan sebelum melakukan baby spa bayinya pendiam (kurang aktif dalam beraktifitas atau merespon), kurang percaya diri dengan orang disekitarnya, sering rewel, kurang ceria, dan menurunnya nafsu makan sehingga berat badan lama kelamaan menurun. Selain itu efek dan manfaat lain yang dapat di peroleh dari baby spa yaitu dapat meningkatkan daya tahan tubuh bayi, menigkatkan IQ, meningkatkan hormon Beta endorphin dalam pertumbuhan, membina ikatan kasih sayang (Bounding attachment), merangsang vagus, mengurangi komplikasi, dan mempercepat proses myelinisasi. Sehingga, peneliti tertarik untuk mengetahui "Hubungan Frekuensi Baby Spa dengan Perkembangan pada Bayi Usia 4-6 Bulan di Klinik Baby Spa Aulia”.

\section{Konsep Baby Spa}

Baby spa merupakan perawatan spa tubuh pada bayi yang dapat dilakukan dengan dua cara, yaitu mandi berendam atau berenang dan pijat (Yahya, 2011).
Spa adalah upaya kesehatan tradisional yang menggunakan pendekatan holistic, melalui perawatan menyeluruh dengan menggunakan metode kombinasi ketrampilan hidroterapi, pijat (massage) yang diselenggarakan secara terpadu untuk menyeimbangkan tubuh, pikiran dan perasaan (body, mind and spirit) (Permenkes, 2004).

Baby spa tubuh bayi dapat dilakukan dengan dua cara, yaitu mandi berendam atau berenang dan pijat (Yahya, 2011).

\section{Mandi Berendam}

Mandi berendam sangat efektif untuk menghilangkan kelelahan dan kejenuhan. Pada bayi dan anak, mandi berendam merupakan pilihan yang tepat untuk membantu menghilangkan kelelahannya.

\section{Pijat Bayi}

Pijat adalah seni perawatan kesehatan dan pengobatan yang dipraktekkan sejak berabad-abad silam. Bahkan, diperkirakan ilmu ini telah dikenal sejak awal manusia diciptakan ke dunia, karena pijat sangat berhubungan erat dengan kehamilan dan proses kelahiran manusia (Roesli, 2010).

Beberapa penelitian membuktikan manfaat berendam dan berenang bagi bayi cukup banyak diantaranya :

1) Berendam dan berenang akan merangsang gerakan motorik bayi.

Dengan bermain air, otot-otot bayi akan berkembang dengan sangat baik, persendian tumbuh secara 
optimal , pertumbuhan badan meningkat, dan tubuh pun menjadi lentur. Dengan kata lain, gerakan di dalam air semua anggota tubuh bayi akan terlatih, karena seluruh anggota tubuh digerakkan mulai dari kaki, tangan, hingga kepala walaupun gerakannya belum sempurna. Bayi belajar bergerak di dalam airakan mampu berjalan lebih awal dibandingkan bayi-bayi lainnya karena kemampuan kontrol otot mereka lebih meningkat. Kemampuan motorik bayi akan berkembang lebih pesat, karena pada saat berenang di dalam air, efek gravitasi sangat rendah sehingga memungkinkan bayi untuk bergerak lebih banyak dan semua otot pun dapat bekerja secara optimal.

2) Bayi yang dilatih berenang akan memiliki keseimbangan tubuh yang lebih baik.

Hasil riset gabungan dari Lancaster University dan Norwegian University of Science and Technology mengungkapkan bahwa bayi yang berenang memiliki keseimbangan yang lebih baik dan dapat lebih mudah meraih sebuah objek dibandingkan bayi yang tidak berenang. Hasil riset juga menyebutkan bahwa pengenalan olahraga renang pada bayi beberapa bulan pasca dilahirkan membantu mereka mengembangkan ketrampilan fisik di kemudian hari.

3) Bayi yang dibiasakan bergerak di dalam air tidak akan takut terhadap air.

Banyak bayi tidak mau mandi karena takut air. Jika kegiatan berenang dikenalkan sejak dini mungkin maka bayi akan terbiasa dengan terbiasa dengan air dan tidak akan takut lagi, bakan sangat senang berada di dalam air dan bermain di air.

4) Berendam dan berenang akan mengasah kemandirian, keberanian, dan kepercayaan diri bayi.

Berenang akan mendorong bayi tumbuh menjadi sosok yang mandiri dan memiliki rasa percaya diri yang tinggi. Kemampuan berenang dibiasakan maka dapat meningkatkan kepercayaan diri dan pengembangan pribadi, fisik, dan emosional. Hal ini juga sangat bermanfaat bagi bayi yang memiliki kelainan bawaan seperti Down Syndrome dan Cerebal Palsy.

5) Berenang dapat meningkatkan IQ (kecerdasan berfikir) dan konsentrasi.

Pada saat berenang bayi menggerakkan seluruh anggota badan, gerakan ini dapat merangsang pertumuhan sarafsaraf tepi sehingga saraf otak menjadi lebih aktif, dan hal ini dapat meningkatkan kepintarannya. Bayi yang berenang sejak dini akan terbiasa mengikuti instruksi atau mendengarkan perkataan orang lain. Hal ini membuat kemampuan kognitifnya makin bekembang. Perkembangan kognitif meliputi berfikir, belajar, dan kemampuan memecahkan masalah.

6) Berendam dan berenang menjadi sarana bermain yang sangat menyenangkan bagi bayi.

Kegiatan ini dapat membuat bayi mengingat kembali masa-masa hidupnya ketika ia berada didalam kandungan. 
7) Berendam dan berenang meningkatkan kualitas pola tidur siang dan malam.

Tidur bayi akan makin lelap. Banyak penelitian membuktikan bahwa tidur lelap pada bayi meningkatkan kecerdasannya.

8) Berenang secara rutin juga dapat mempengaruhi nafsu makan bayi. Gerakan yang banyak di dalam air akan meningkatkan metabolisme tubuh bayi sehingga secara otomatis mafsu makan bayi akan meningkat.

Hal-hal yang perlu diperhatikan dan dipersiapkan dalam berenang, Riksani (2014) :

1. Periksa kondisi bayi

Sebelum mengajak bayi berenang, sebaiknya memeriksakan kondisi kesehatan bayi ke dokter terdekat.

2. Tahap pengenalan air

Pada tahap awal sebagai tahap pengenalan bayi terhadap air, sebelum mengajak ke kolam renang bayi dapat di latih bermain air atau berenang di kolam plastik terlebih dahulu.

3. Kedalaman kolam

Sebaiknya memilih kolam renang yang memiliki bagian khusus untuk anak-anak, biasanya yang tingkat kedalamannya hanya sebatas pinggang. Kolam renang yang terlalu dalam mempunyai banyak efek negatif, seperti resiko terjadinya tenggelam, hal ini akan membuat sikecil tidak nyaman tetapi justru membuat takut terhadap takut dengan air.

4. Suhu air

Suhu kolam harus diperhatikan dengan baik. Sebaiknya, suhu kolam tidak terlalu dingin atau terlalu panas. Usahakan agar suhunya hampir sama dengan suhu tubuh. Jika suhunya terlalu dingin atau terlalu panas, bisa menyebabkan sikecil tidak nyaman bahkan sakit. Suhu air berkisar 34$35^{0}$ Celcius (Yahya, 2011).

5. Kejernihan air

Kebersihan air kolam pun harus dijaga, air di dalamnya haruslah jernih dan tidak keruh sehingga tidak berbahaya jika saat berenang tertelan oleh si kecil. Hindari pula kolam renang yang mengandung kaporit karena akan berdampak buruk bagi kesehatannya terutama pada mata dan kulitnya.

6. Lantai kolam

Perhatikan pula kebersihan lantai kolam. Jika lantai kolam tidak dibersihkan, akan terasa licin, tentu ini akan membahayakan bagi si kecil karena mengakibatkan mudah terpeleset.

7. Pengawasan dan pendampingan orangtua

Tak sedikit bayi bayi yang nyaris tenggelam atau tersedak akibat mulut dan hidungnya kemasukan air.

\section{Waktu yang tepat untuk berenang}

Pada tahun pertama kehidupannya, bayi mengalami perkembangan yang pesat pada otaknya. Renang bayi telah diketahui bermanfaat dalam merangsang perkembangan otak secara optimal, menguatkan saraf, dan meningkatkan pertumbuhan motorik. Air sebagai media dalam renang ini, memungkinkan bayi untuk bisa bergerak dengan bebas. Hal ini akan berperan dalam mendukung tumbuh kembang bayi yang lebih baik.

Usia 4-6 bulan merupakan saat yang paling tepat bagi bayi untuk mengenal kolam renang. Hal ini dikarenakan refleks akuatiknya belum menghilang 
(kemampuan untuk segera menarik nafas sebelum menyentuh air), bayi juga mempunyai naluri untuk mengapung dan menyelam yang mencegahnya menelan air saat berada di dalam air. Itulah sebabnya usia ini merupakan usia ideal, yang memungkinkan untuk bisa melatih bayi berenang dengan mudah. Lamanya berenang dilakukan berkisar 10-15 menit, dua kali seminggu. Jangan terlalu lama karena akan menimbulkan hipotermi (penurunan suhu tubuh) yang mengakibatkan bayi mengalami stres dingin (cold stres) (Riksani, 2014).

\section{Pijat}

Pijat bayi biasa disebut dengan stimulus touch. Pijat bayi dapat diartikan sebagai sentuhan komunikasi yang nyaman antara ibu dan bayi. Jadi, pijat bayi ini merupakan suatu ungkapan rasa kasih sayang antara orang tua dengan anak lewat sentuhan pada kulit yang dapat memberikan dampak luar biasa (Siska, 2010).

Menurut Yahya (2011), pijat memiliki manfaat positif terhadap tubuh terkait dengan efek biokimia dan klinis yang diciptakannya, diantaranya adalah :

1. Efek biokimia yang positif

a) Menurunkan kadar hormon stress (catecholamine)

b) Meningkatkan kadar serotonin

2. Efek klinis dari pijat

a) Meningkatkan jumlah dan kekuatan system imunitas/ kekebalan, yaitu sel pembunuh kuman alami yang dimiliki tubuh

b) Mengubah gelombang otak secara positif

c) Memperbaiki sirkulasi darah dan pernapasan d) Merangsang fungsi pencernaan serta pembuangan

e) Meningkatkan kenaikan berat badan

f) Mengurangi depresi dan ketegangan

g) Meningkatkan kesiagaan

h) Membuat tidur lelap

i) Mengurangi rasa sakit

j) Mengurangi kembang dan kolik (sakit perut)

k) Membina ikatan kasih sayang antara bayi/ anak dan pemijat

1) Meningkatkan volume air susu ibu

m)Dapat mendeteksi adanya kelainan tumbuh kembang

\section{Waktu pijat dan kondisi}

Menurut Riksani (2014), waktu yang tepat dalam melakukan pijat adalah :

Pijat bayi bisa dilakukan segera setelah bayi lahir, sesuai dengan keinginan orangtua. Tentu, jika pemijatan dilakukan lebih dini, bayi akan mendapatkan manfaat dan keuntungan yang lebih besar. Hasil yang lebih optimal akan didapatkan jika pemijatan dilakukan sejak bayi lahir secara teratur setiap hari hingga bayi berusia 6-7 bulan.

Pijat dapat dilakukan lebih dari 1 kali dalam sehari. Waktu terbaik untuk melakukannya saat bayi dalam keadaan terjaga dengan baik.Hindari saat-saat ketika bayi Anda terlihat lapar, lelah, atau sedang menangis.

Kondisi-kondisi yang tidak boleh ibu lakukan saat melakukan pijat bayi:

1. Memijat bayi langsung setelah makan

2. Memijat bayi pada saat kondisi bayi tidak sehat

3. Memijat bayi pada saat tidak mau dipijat

4. Memaksakan posisi pijat tertentu pada bayi 
5. Membangunkan bayi khusus untuk pemijatan (Riksani, 2014).

\section{Konsep Perkembangan}

Menurut Wong (2000) yang dikutip dalam Hidayat (2011), Perkembangan merupakan bertambah sempurnanya fungsi alat tubuh yang dapat dicapai melalui tumbuh kematangan dan belajar.

Perkembangan adalah bertambahnya struktur dan fungsi tubuh yang lebih kompleks dalam kemampuan gerak kasar, gerak halus, bicara dan bahasa serta sosialisasi dan kemandirian (Kemenkes RI, 2010).

Pertumbuhan terjadi secara simultan dengan perkembangan.Berbeda dengan pertumbuhan, perkembangan merupakan hasil interaksi kematangan susunan saraf pusat dengan organ yang dipengaruhinya, misalnya perkembangan dengan system neuromuskuler, kemampuan berbicara, emosi dan sosialisasi.Kesemua fungsi tersebut berperan penting dalam kehidupan manusia yang utuh (Kemenkes RI, 2010).

Perkembangan pada anak mencakup perkembangan motorik halus, perkembangan motorik kasar, perkembangan bahasa, dan perkembangan perilaku atau adaptasi sosial (Hidayat, 2011).

1) Perkembangan motorik halus pada bayi usia 4-6 bulan adalah sudah mulai mengamati benda, mengeksplorasi benda yang dipegang, mengambil obyek dengan tangan tertangkup, menahan benda di kedua tangan secara simultan.

2) Perkembangan motorik kasar pada bayi usia 4-6 bulan adalah pada perubahan dalam aktivitas, seperti telungkup pada alas, dan sudah mulai mengangkat kepala dengan melakukan gerakan menekan kedua tangannnya, mampu memalingkan kepala ke kanan dan ke kiri, berguling dan terlentang ke tengkurap.

3) Perkembangan bahasa pada bayi usia 4-6 bulan adalah menirukan bunyi tau kata-kata, menoleh ke arah suara atau sumber bunyi, menggunakan vokalisasi semakin banyak.

4) perkembangan perilaku atau adaptasi social pada bayi usia 4-6 bulan dapat diawali dengan mengamati tangannya, tersenyum spontan jika diajak tersenyum, mengenal ibunya, senang menatap wajah-wajah yang dikenal.

\section{METODE PENELITIAN}

Penelitian ini menggunakan desain deskriptif korelasi yaitu metode penelitian yang menggambarkan suatu keadaan secara objektif untuk melihat hubungan antara 2 variabel pada situasi atau kelompok tertentu (Notoatmodjo, 2012). Sedangkan metode pendekatan peniliti menggunakan pendekatan cross sectional yaitu merupakan rancangan penelitian dengan melakukan pengukuran atau pengamatan sekali waktu dan pada saat yang bersamaan (Setiawan dan Sayono, 2011).

Lokasi yang akan dijadikan sebagai daerah penelitian adalah di Klinik Baby Spa Aulia. Penelitian ini akan dilakukan pada bulan Agustus 2017.

Populasi dalam penelitian ini adalah seluruh bayi umur 4-6 bulan pada bulan Juni 2017 di Klinik Baby Spa Aulia sejumlah 56 bayi. Sampel penelitian adalah sebagian yang diambil dari keseluruhan objek yang diteliti dan dianggap mewakili populasi (Sugiyono, 2010). 
Teknik pengambilan sampel dalam penelitian ini adalah menggunakan purposive sampling yaitu dimana teknik pengambilan sampel ini berdasarkan pada kriteria tertentu dari satu tujuan yang spesifik yang sebelumnya ditetapkan oleh peneliti, subyek yang memenuhi kriteria tersebut menjadi anggota sampel (Arikunto, 2010). Supaya hasil penelitian sesuai dengan kriteria tertentu yang ditetapkan, kriteria ini berupa kriteria inklusi dan kriteria eksklusi (Saryono, 2010).

Adapun kriteria sampel yang diambil adalah memenuhi kriteria sebagai berikut :

Kriteria Inklusi adalah :

1. Bayi usia 4-6 bulan yang melakukan baby spa di Klinik Baby Spa Aulia

Untuk kriteria ekslusi yaitu ciri-ciri anggota populasi yang tidak dapat diambil sebagai sampel (Notoadmodjo, 2012). Yang termasuk dalam kriteria eksklusi dalam penelitian ini yaitu :

1. Bayi yang mengalami cacat fisik dan mental.

2. Bayi yang tidak mendapatkan perlakuan baby spa sepenuhnya / hanya melakukan 1 treatment (pijat/ renang saja).

Penelitian ini menggunakan teknik pengambilan sampel Purposive Sampling yaitu dimana teknik pengambilan sampel ini berdasarkan pada kriteria tertentu dari suatu tujuan yang spesifik yang sebelumnya ditetapkan oleh peneliti, subyek yang memenuhi kriteria tersebut menjadi anggota sampel (Arikunto, 2010).

\section{HASIL}

\section{ANALISIS UNIVARIAT}

\section{Usia}

Bayi yang berusia 4-6 bulan yang telah melakukan baby spa pada bulan Juni di Klinik Baby Spa Aulia.
Tabel 1.1 Distribusi Frekuensi Berdasarkan Usia Bayi yang Berusia 4-6 Bulan di Klinik Baby Spa Aulia

\section{Statistics}

\begin{tabular}{|l|l|l|l|}
\hline & $\begin{array}{l}\text { Usia } \\
\text { Bayi } \\
\text { yang } \\
\text { Mengik } \\
\text { uti Baby }\end{array}$ & $\begin{array}{l}\text { Frekuen } \\
\text { si Baby } \\
\text { Spa }\end{array}$ & $\begin{array}{l}\text { Perkemban } \\
\text { San Bayi }\end{array}$ \\
\hline $\begin{array}{c}\text { N Valid } \\
\text { Missin } \\
\text { g }\end{array}$ & 0 & 34 & 34 \\
\hline
\end{tabular}

Berdasarkan tabel 1.1 dapat diketahui bahwa responden yang mengikuti baby spa sebanyak 34 bayi.

Usia Bayi yang Mengikuti Baby Spa

\begin{tabular}{|c|l|l|l|l|}
\hline & $\begin{array}{l}\text { Freque } \\
\text { ncy }\end{array}$ & $\begin{array}{l}\text { Percen } \\
\mathrm{t}\end{array}$ & $\begin{array}{l}\text { Valid } \\
\text { Percent }\end{array}$ & $\begin{array}{l}\text { Cumulat } \\
\text { ive } \\
\text { Percent }\end{array}$ \\
\hline $\begin{array}{c}\text { Valid } 4 \\
\text { bulan } \\
5 \\
\text { bulan }\end{array}$ & 10 & 29.4 & 29.4 & 29.4 \\
6 & 32.4 & 32.4 & 61.8 \\
$\begin{array}{l}\text { bulan } \\
\text { Total }\end{array}$ & 13 & 38.2 & 38.2 & 100.0 \\
\hline
\end{tabular}

Berdasarkan tabel 1.2 dapat diketahui bahwa sebagian besar responden yang melakukan baby spa berusia 6 bulan sebanyak $13(38,2 \%)$ bayi, responden pada usia 5 bulan sebanyak 11 $(32,4 \%)$ bayi, sedangkan responden yang paling sedikit berusia 4 bulan sebanyak $10(29,4 \%)$ bayi.

\section{Frekuensi}

Tabel 1.3 Distribusi Frekuensi Berdasarkan Frekuensi Baby Spa bayi usia 4-6 bulan di Klinik Baby Spa Aulia 
Frekuensi Baby Spa

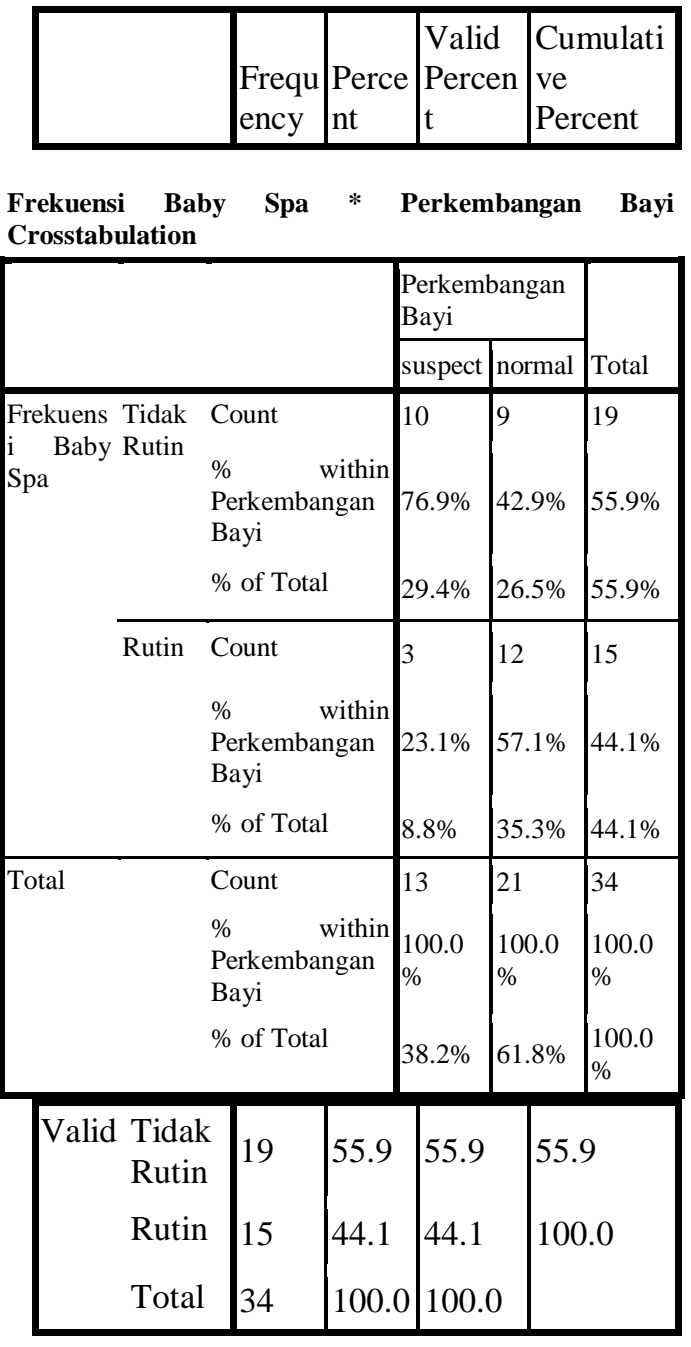

Berdasarkan tabel 1.3 dapat diketahui bahwa sebagian besar responden yang melakukan baby spa secara tidak rutin yaitu sebanyak $19(55,9 \%)$ bayi, sedangkan responden yang melakukan baby spa secara rutin yaitu sebanyak $15(44,1 \%)$ bayi.

\section{Perkembangan}

Tabel 1.4 Distribusi Frekuensi Berdasarkan Perkembangan Bayi Usia 4-6 Bulan di Klinik Baby Spa Aulia

\begin{tabular}{|l|l|l|l|l|}
\hline \multicolumn{1}{|c|}{ Perkembangan Bayi } \\
\hline & $\begin{array}{l}\text { Frequen } \\
\text { cy }\end{array}$ & Percent & $\begin{array}{l}\text { Valid } \\
\text { Percent }\end{array}$ & $\begin{array}{l}\text { Cumul } \\
\text { ative } \\
\text { Percent }\end{array}$ \\
\hline $\begin{array}{l}\text { Val suspect } \\
\text { id normal }\end{array}$ & 13 & 38.2 & 38.2 & 38.2 \\
& 21 & 61.8 & 61.8 & 100.0 \\
\hline
\end{tabular}

Perkembangan Bayi

\begin{tabular}{|c|c|c|c|c|}
\hline & $\begin{array}{l}\text { Frequen } \\
\text { cy }\end{array}$ & Percent & $\begin{array}{l}\text { Valid } \\
\text { Percent }\end{array}$ & $\begin{array}{l}\text { Cumul } \\
\text { ative } \\
\text { Percent }\end{array}$ \\
\hline $\begin{array}{cc}\text { Val } & \text { suspect } \\
\text { id } & \text { normal } \\
& \\
& \text { Total }\end{array}$ & $\begin{array}{l}13 \\
21 \\
34\end{array}$ & $\begin{array}{l}38.2 \\
61.8 \\
100.0\end{array}$ & $\begin{array}{l}38.2 \\
61.8 \\
100.0\end{array}$ & $\begin{array}{l}38.2 \\
100.0\end{array}$ \\
\hline
\end{tabular}

Berdasarkan tabel 1.4 dapat diketahui bahwa sebagian besar responden yang perkembangannya normal yaitu sebanyak $21(61,8 \%)$ bayi sedangkan responden yang perkembangannya suspect yaitu sebanyak $13 \quad(38,2 \%)$ bayi.

\section{ANALISIS BIVARIAT}

Analisis bivariat pada bagian ini menyajikan hasil analisis hubungan frekuensi baby spa dengan perkembangan pada usia bayi 4-6 bulan di Klinik Baby Spa Aulia.

Tabel 1.5 Hubungan frekuensi baby spa dengan perkembangan pada bayi usia 4-6 bulan di Klinik Baby Spa Aulia

Hasil analisis bivariat hubungan frekuensi baby spa dengan perkembangan pada bayi usia 4-6 bulan di Klinik Baby Spa Aulia, adalah sebagai berikut :

Tabel 1.6 Hubungan frekuensi baby spa dengan perkembangan pada bayi usia 4-6 bulan di Klinik Baby Spa Aulia

Case Processing Summary

\begin{tabular}{|c|c|c|c|c|c|c|}
\hline & \multicolumn{6}{|c|}{ Cases } \\
\hline & \multicolumn{2}{|c|}{ Valid } & \multicolumn{2}{|c|}{ Missing } & \multicolumn{2}{|c|}{ Total } \\
\hline & $\mathrm{N}$ & Percent & $\mathrm{N}$ & Percent & $\mathrm{N}$ & Percent \\
\hline $\begin{array}{l}\text { Frekuensi } \\
\text { Baby Spa } \\
\text { * } \\
\text { Perkemba } \\
\text { ngan Bayi }\end{array}$ & 34 & $100.0 \%$ & 0 & $.0 \%$ & $\begin{array}{l}3 \\
4\end{array}$ & $100.0 \%$ \\
\hline
\end{tabular}


Berdasarkan tabel 1.6, menyatakan bahwa subjek penelitian yaitu sebanyak 34 bayi.

Berdasarkan tabel 1.5, dapat diketahui bahwa dari $19(55,9 \%)$ bayi dengan frekuensi baby spa yang tidak rutin pada bayi yang perkembangannya suspect yaitu sebanyak $10(76,9 \%)$ bayi, dan frekuensi baby spa yang tidak rutin pada bayi yang perkembangannya normal yaitu sebanyak $9(42,9 \%)$ bayi. Sedangkan dari $15(44,1 \%)$ bayi dengan frekuensi rutin pada bayi yang perkembangannya suspect yaitu sebanyak $3(23,1 \%)$ bayi, dan frekuensi baby spa yang rutin pada bayi yang perkembangannya normal yaitu sebanyak $12(57,1 \%)$ bayi.

Berdasarkan uji Chi Square didapat pvalue 0,000 . Oleh karena $p$-value $=$ $0,000<\alpha(0,05)$, disimpulkan bahwa ada hubungan frekuensi baby spa dengan perkembangan pada bayi usia 4-6 bulan di Klinik Baby Spa Aulia. Hasil Ratio Odds yaitu 5,74 artinya frekuensi baby spa yang rutin dilakukan pada bayi usia 4-6 bulan lebih baik perkembangannya 5,74 lebih baik dibandingkan bayi yang melakukan baby spa dengan frekuensi tidak rutin.

Berdasarkan uji Chi Square didapat pvalue 0,378 . Oleh karena $\mathrm{p}$-value $=$ $0,378<\alpha(0,05)$, disimpulkan bahwa ada hubungan yang signifikan antara frekuensi baby spa dengan perkembangan pada bayi usia 4-6 bulan di Klinik Baby Spa Aulia

\section{PEMBAHASAN}

\section{Frekuensi Baby Spa}

Frekuensi merupakan banyak kejadian yang ada pada kelas-kelas tertentu (Sugiono, 2009). Dalam penelitian ini terdapat bahwa dari 34 bayi usia 4-6 bulan, pada frekuensi baby spa dengan kategori tidak rutin melakukan baby spa yaitu sebanyak $19 \quad(55,9 \%)$ sedangkan frekuensi baby spa dengan kategori rutin melakukan baby spa yaitu sebanyak $15(44,1 \%)$ bayi. Baby spa termasuk dalam kategori rutin bila dilakukan setiap dua kali seminggu, dan baby spa termasuk dalam kategori tidak rutin bila dilakukan kurang dari dua kali seminggu.

Frekuensi untuk melakukan baby spa di Klinik Baby Spa Aulia pada kategori tidak rutin dikarenakan oleh beberapa faktor diantaranya adalah pendapatan ekonomi. Baby spa baik dilakukan setiap dua kali seminggu, baby spa baik dilakukan secara teratur (Riksani, 2014). Bayi yang sering mendapatkan baby spa akan baik perkembangannya dibandingkan bayi yang kurang atau tidak mendapatkan baby spa (Yahya, 2011). Untuk mendapat satu kali treatment baby spa di Klinik Baby Spa Aulia a membayar sebesar Rp. 100.000,-. Hal ini dapat mempengaruhi frekuensi untuk melakukan baby spa bagi pendapatan ekonomi yang kurang.

Selain itu, frekuensi untuk melakukan baby spa pada kategori tidak rutin adalah responden yang berdomisili jauh dari Klinik Baby Spa Aulia. Karena letak rumah responden yang jauh dari Klinik Baby Spa Aulia sehingga perlu ada nya transportasi yang memadai untuk dapat menjangkau datang ke Klinik Baby Spa Aulia.

Kondisi bayi juga berpengaruh terhadap frekuensi untuk melakukan baby spa. Hal-hal yang perlu diperhatikan dan dipersiapkan saat melakukan baby spa salah satunya adalah periksa kondisi bayi (Riksani, 2014). Saat bayi sedang sakit atau kurang sehat tentunya tidak dapat melakukan baby spa. Hal ini akan 
memperburuk kondisi bayi apabila dipaksakan melakukan baby spa. Dengan kondisi bayi yang sehat pastinya akan membuat bayi semakin lebih tenang dan nyaman ketika melakukan baby spa (Riksani, 2014).

\section{Perkembangan bayi usia 4-6 bulan}

Perkembangan adalah bertambahnya struktur dan fungsi tubuh yang lebih kompleks dalam kemampuan gerak kasar, gerak halus, bicara dan bahasa serta sosialisasi dan kemandirian (Kemenkes RI, 2010).

Alat ukur untuk mengukur perkembangan salah satunya adalah DDST (Denver Developmental Screening Test). DDST yaitu suatu tes untuk melakukan skrining/pemeriksaan terhadap perkembangan anak usia satu bulan sampai dengan enam tahun. Tujuan DDST adalah mengkaji dan mengetahui perkembangan anak yang meliputi motorik kasar, bahasa, adaptif-motorik halus dan personal sosial pada anak usia satu bulan sampai dengan enam tahun (Saryono, 2010).

Perkembangan pada anak mencakup perkembangan motorik halus, perkembangan motorik kasar, perkembangan bahasa, dan perkembangan perilaku atau adaptasi sosial. Perkembangan motorik halus pada bayi usia 4-6 bulan adalah sudah mulai mengamati benda, mengeksplorasi benda yang dipegang, mengambil obyek dengan tangan tertangkup, menahan benda di kedua tangan secara simultan. Perkembangan motorik kasar pada bayi usia 4-6 bulan adalah pada perubahan dalam aktivitas, seperti telungkup pada alas, dan sudah mulai mengangkat kepala dengan melakukan gerakan menekan kedua tangannnya, mampu memalingkan kepala ke kanan dan ke kiri, berguling dan terlentang ke tengkurap. Perkembangan bahasa pada bayi usia 4-6 bulan adalah menirukan bunyi tau kata-kata, menoleh ke arah suara atau sumber bunyi, menggunakan vokalisasi semakin banyak. Sedangkan Perkembangan perilaku atau adaptasi sosial pada bayi usia 4-6 bulan dapat diawali dengan mengamati tangannya, tersenyum spontan jika diajak tersenyum, mengenal ibunya, senang menatap wajah-wajah yang dikenal (Hidayat, 2011).

Faktor-faktor yang mempengaruhi perkembangan yaitu faktor herediter/genetik dan faktor lingkungan (lingkungan pranatal, faktor postnatal). Faktor postnatal juga dipengaruhi oleh beberapa faktor yaitu lingkungan biologis, faktor fisik, faktor psikososial, faktor keluarga dan adat istiadat (Soetjiningsih, 2014).

Berdasarkan penilaian perkembangan dengan menggunakan DDST, terhadap hasil perkembangan di Klinik Baby Spa Aulia adalah dari 34 bayi usia 4-6 bulan lebih besar pada perkembangan normal yaitu sebanyak 22 (64,7\%), sedangkan pada perkembangan suspect yaitu sebanyak $12(35,3 \%)$ bayi.

Pengukuran perkembangan ada tiga interpretasi hasil skrining DDST II yaitu normal jika didapatkan hasil tidak ada delayed. Penilaian item $\mathrm{T}=$ "Terlambat" $(\mathrm{D}=$ Delayed $) . \quad$ Nilai "Terlambat"diberikan jika anak "Gagal" (G) atau "Menolak" (M) melakukan tugas untuk item di sebelah kiri garis usia sebab tugas tersebut memang ditujukan untuk anak yang lebih muda. maksimal satu caution. Penilaian item $\mathrm{P}=$ "Peringatan" $(\mathrm{C}=$ Caution). diberikan jika anak "Gagal" (G) atau "Menolak" (M) melakukan tugas untuk item yang dilalui pada daerah gelap kotak. Rujukannya adalah lakukan skrining rutin. 
Curiga/suspect jika didapatkan hasil dengan dua atau lebih caution, dan/atau terdapat satu atau lebih delayed. Rujukannya adalah lakukan uji ulang satu sampai dua minggu kemudian untuk menghilangkan faktor sesaat seperti rasa takut, sakit, atau kelelahan. Tidak Stabil/Unstable jika didapatkan hasil dengan satu atau lebih delayed, dan/atau dua atau lebih caution. Dalam hal ini delayed atau caution harus disebabkan oleh karena penolakan (refusal) bukan karena kegagalan (fail). Rujukannya adalah dilakukan uji ulang satu sampai dua minggu ke depan (Adriana , 2011).

Pada 12 bayi yang memiliki perkembangan suspect pada kategori tidak rutin melakukan baby spa yaitu sejumlah 10 bayi $(83,3 \%)$, dan pada kategori rutin melakukan baby spa yaitu sejumlah $2(16,7 \%)$ bayi. Sedangkan pada 22 bayi yang memiliki perkembangan normal pada yaitu pada kategori tidak rutin melakukan baby spa yaitu sejumlah 9 $(40,9 \%)$ dan pada kategori rutin melakukan baby spa yaitu sejumlah 13 bayi $(59,1 \%)$ bayi.

\section{Hubungan Frekuensi Baby Spa dengan Perkembangan pada Bayi Usia 4-6 Bulan di Klinik Baby Spa Aulia}

Analisis bivariat ini akan membahas hubungan frekuensi baby spa dengan perkembangan pada bayi usia 4-6 bulan di Klinik Baby Spa Aulia. Berdasarkan hasil penelitian didapatkan nilai $\mathrm{p}$ value sebesar 0,043 $<$ nilai $\alpha=0,05$ yang menunjukkan bahwa ada hubungan yang signifikan antara frekuensi baby spa dengan perkembangan pada bayi usia 4-6 bulan.

Dalam penelitian ini responden yang frekuensi baby spa dengan kategori tidak rutin melakukan baby spa memiliki perkembangan suspect yaitu sejumlah $10(52,6 \%)$, dan memiliki perkembangan normal yaitu sejumlah $9(47,4 \%)$. Periode penting dalam tumbuh kembang anak adalah masa bayi dan balita. Pada masa bayi dan balita, perkembangan kemampuan berbahasa, kreativitas, kesadaran sosial, emosional, dan intelegensia berjalan sangat cepat dan merupakan landasan perkembangan berikutnya. Perkembangan anak terdapat masa kritis, sehingga diperlukan rangsangan atau stimulasi yang berguna agar potensi anak berkembang secara optimal. Anak yang mendapat stimulasi yang terarah dan teratur akan lebih cepat berkembang dibandingkan dengan anak yang kurang atau tidak mendapat stimulasi (Soetjiningsih, 2012).

Stimulasi merupakan cikal bakal dalam proses belajar pada anak. Stimulasi ini akan mengembangkan perkembangan mental psikososial anak seperti kecerdasan, ketrampilan kemandirian, moral etika dan sebagainya. Anak yang mendapatkan stimulasi (baby spa) yang terarah dan teratur akan lebih cepat berkembang dibandingkan dengan anak yang kurang atau tidak mendapatkan stimulasi (Hidayat, 2005).

Hasil penelitian ini sesuai dengan penelitian yang dilakukan oleh Halimah, Suharto dan Fajriah (2012) tentang Pengaruh Stimulasi Bayi terhadap Perkembangan Motorik Kasar pada Bayi Usia 3-8 Bulan. Hasil penelitian menunjukkan pemberian perlakuan berupa pijat bayi, senam bayi, dan berbagai bentuk permainan memberikan pengaruh yang bermakna dengan peningkatan perkembangan motorik kasar bayi.

Baby spa merupakan salah satu stimulasi taktil pada bayi. Stimulasi taktil merupakan suatu jenis 
rangsangan sensori yang penting untuk perkembangan bayi yang optimal. Sensasi sentuhan adalah yang paling berkembang pada saat lahir., karena sensasi ini telah berfungsi sejak dalam kandungan sebelum sensasi yang lain berkembang. Contoh rangsangan taktil yang dapat dilakukan dan penting antara lain memegang, menimang, menguru, menepuk, menggoncangdan gerakan termasuk memijat dan berenang. Cara lain yang dapat digunakan untuk merangsang dengan taktil adalah melalui mainan yang mempunyai permukaan yang lembut, licin, fleksibel dan kaku (Hammer dan Turner, 1990, dalam Soedjatmiko, 2006).

Sedangkan pada frekuensi baby spa dengan kategori rutin melakukan baby spa memiliki perkembangan suspect yaitu sejumlah 2 (13,3\%), dan memiliki perkembangan normal yaitu sejumlah $13(86,7 \%)$ bayi. Faktorfaktor lain yang mempengaruhi perkembangan diantaranya Cinta dan kasih sayang orang tua terhadap anak. Salah satu hak anak adalah hak untuk dicintai dan dilindungi namun sebaliknya kasih sayang yang berlebihan justru akan menjurus kearah memanjakan yang akan menghambat bahkan mematikan perkembangan kepribadian anak (Soetjiningsih, 20114).

Kualitas dari interaksi juga dapat mempengaruhi proses perkembangan anak. Kualitas dari interaksi antara anak dan orangtua dilihat dari pemahaman terhadap kebutuhan masing-masing dan upaya optimal untuk memenuhi kebutuhannya yang dilandasi rasa kasih sayang. Hubungan interaksi antara anak dan orangtua baik maka akan mendukung perkembangan anak yang optimal. Apalagi pada orang tua yang sibuk karena bekerja, dan pengasuh juga kurang memberikan interaksi sehingga akan mengurangi intensitas waktu untuk berinteraksi kepada anaknyan dan dapat mengakibatkan perkembangan terhambat (Soetjiningsih, 20114).

Pendidikan ayah /ibu dapat mempengaruhi proses perkembangan pada anak. Semakin tinggi pendidikan seseorang, informasi yang dimiliki lebih luas dan lebih mudah diterima termasuk informasi tentang pertumbuhan dan perkembangan anak. Sedangkan bila tingkat pendidikan seseorang rendah maka akan berakibat terputusnya informasi yang diperoleh pada jenjang pendidikan yang lebih. Pada saat orangtua berpendidikan tinggi maka orang tua dapat menerima informasi dari luar tentang pengasuhan anak yang baik, pendidikannya, dan lainnya begitu pula sebaliknya (Soetjiningsih, 2014).

Jumlah saudara berkaitan dengan stimulasi yang dilakukan oleh sesama saudara kandungnya. Posisi anak dalam keluarga dapat mempengaruhi pertumbuhan dan perkembangan. Hal ini dapat dilihat pada anak pertama atau tunggal, dalam aspek perkembangan secara umum kemampuan intelektualnya lebih menonjol dan cepat berkembang karena sering berinteraksi dengan orang dewasa, akan tetapi perkembangan motoriknya terkadang terlambat karena tidak ada stimulasi yang biasanya yang dilakukan oleh saudara kandungnya (Hidayat, 2005).

Jenis kelamin dalam keluarga berpengaruh terhadap perkembangan anak. Wanita di masyarakat masih dianggap berstatus rendah maka sering ditemui kematian bayi dan malnutrisi pada wanita yang lebih tinggi daripada laki-laki. 
Hal ini sesuai dengan penelitian Anindita (2013) tentang Pengaruh Pijat Bayi terhadap Perkembangan Bayi. Dalam penelitian tersebut menunjukkan ada hubungan yang signifikan antara jenis kelamin dengan perkembangan bayi. Judarwanto dan Dewi (2012), menyebutkan pada anak perempuan pada usia middle childhood kelenturan fisiknya $5 \%$ $10 \%$ lebih baik daripada laki-laki, tetapi untuk kemampuan fisik seperti berlari, melompat, dan melempar termasuk perkembangan motorik kasar pada anak laki-laki lebih baik daripada anak perempuan. Pada penelitian ini, didapatkan pada jenis kelamin perempuan yang mengalami perkembangan suspectsebanyak dua responden., sedangkan pada responden yang berjenis kelamin laki-laki sebanyak empat responden. Hal ini menunjukkan pijat bayi lebih berpengaruh terhadap peningkatan perkembangan pada jenis kelamin laki-laki. Fakta ini memungkinkan pijat bayi tidak memberikan pengaruh secara statistik terhadap perkembangan bayi.

Stabilitas pada rumah tangga dan kepribadian ayah/ibu. Pada keluarga harmonis tumbuh kembang anak akan lebih baik. Sebaliknya pada keluarga yang kurang harmonis, maka tumbuh kembang anak tidak akan berkembang secara baik. Begitu pula kepribadian ayah dan ibu yang terbuka tentu pengaruhnya berbeda terhadap tumbuh kembang anak. Keluarga adalah orang utama yang sangat berperan dalam pembentukan tumbuh kembang (Soetjiningsih, 20114).

Adat istiadat dan norma- norma yang dianggap tabu. Budaya lingkungan dalam hal ini adalah masyarakat dapat mempengaruhi pertumbuhan dan perkembangan anak dalam memahami dan mempersepsikan pola hidup sehat.
Hal ini dapat terlihat apabila kehidupan atau berperilaku mengikuti budaya yang ada kemungkinan besar dapat menghambat dalam aspek pertumbuhan dan perkembangan. Sebagai contoh anak yang dalam usia tumbuh kembang membutuhkan makanan yang bergizi karena terdapat adat atau budaya tertentu terdapat makanan yang dilarang. Pada masa tertentu padahal makanan tersebut dibutuhkan untuk perbaikan gizi, maka tentu akan mengganggu atau menghambat pada masa tumbuh kembang. Seperti halnya budaya kehidupan kota akan berbeda dengan kehidupan desa dalam pola kebiasaan sehingga kemungkinan besar dapat mempengaruhi tumbuh kembang (Hidayat, 2008)

\section{SIMPULAN DAN SARAN}

\section{Simpulan}

Berdasarkan hasil penelitian tentang hubungan frekuensi dengan perkembangan pada usia 4-6 bulan di Klinik Baby Spa Aulia dapat ditarik kesimpulan sebagai berikut :

1. Sebagian besar responden frekuensi baby spa pada kategori tidak rutin melakukan baby spa memiliki jumlah paling banyak dengan perkembangan suspect yaitu sejumlah $10(52,6 \%)$, dan memiliki perkembangan normal yaitu sejumlah $9 \quad(47,4 \%)$. Sedangkan pada frekuensi baby spa dengan kategori rutin melakukan baby spa memiliki perkembangan suspect yaitu sejumlah $2(13,3 \%)$, dan memiliki perkembangan normal yaitu sejumlah $13(86,7 \%)$ bayi.

2. Sebagian besar bayi usia 4-6 bulan memiliki perkembangan normal dengan frekuensi baby spa pada kategori tidak rutin melakukan 
baby spa yaitu sejumlah $9(40,9 \%)$ dan pada frekuensi baby spa pada kategori rutin melakukan baby spa yaitu sejumlah $13(59,1 \%)$ bayi.

3. Terdapat hubungan yang signifikan pada frekuensi baby spa terhadap perkembangan pada bayi usia 4-6 bulan di Klinik Baby Spa Ananda Ambarawa dengan p-value $0,043<0,05$ yang berarti ada hubungan frekuensi baby spa dengan perkembangan bayi usia 46 bulan.

\section{Saran}

Berdasarkan hasil analisis dan simpulan yang didapat dari hasil penelitian, penulis menyampaikan saran sebagai berikut :

\section{Bagi Bayi}

Dapat merangsang dan dijadikan salah satu cara alternatif yang baik dalam memberikan stimulasi sehingga mampu meningkatkan kualitas pertumbuhan dan perkembangannya.

\section{Bagi Masyarakat}

Diharapkan dapat menjadikan masukan khususnya mengenai pola asuh pertumbuhan dan perkembangan sehingga dapat meningkatkan pengetahuannya tentang baby spa dan perkembangan anaknya serta selalu memantau pertumbuhan bayinya agar mencapai pertumbuhan yang optimal agar tidak mengalami keterlambatan perkembangan.

\section{Bagi Peneliti}

Agar dapat meningkatkan kemampuan pengetahuan dan wawasan tentang metodologi penelitian dan pengolahan data sehingga dapat menghasilkan penelitian yang baik dan terinci dan bagi peneliti lain agar dapat mengembangkan penelitian dengan menambah variabel penelitian yaitu tentang faktor-faktor lain yang mempengaruhi baby spa dengan perkembangan.

\section{Bagi Institusi}

Diharapkan dapat menyediakan referensi yang terbaru mengenai frekuensi baby spa dengan perkembangan, dan meningkatkan pengetahuan tentang baby spa dan dapat dijadikan sebagai sumber referensi.

\section{DAFTAR PUSTAKA}

Andriani, M dan Wiratmadi, B. 2010. Pengantar Gizi Masyarakat. Kencana Pranada Media Group. Jakarta

Arikunto. 2010. Prosedur Penelitian Suatu Pendekatan Praktik. Jakarta

Badan Pusat Statistik. 2007. Statistik Indonesia. Jakarta : BPS

Dariyo, Agoes. 2007. Psikologi Perkembangan Anak Tiga Tahun Pertama. Bandung : Refika Aditama

Depkes RI, 2006. Pemantauan Pertumbuhan Balita. Jakarta : Direktorat Jenderal Bina Kesehatan Masyarakat. Jakarta

Hidayat, Aziz Alimul. 2005. Pengantar ilmu 
Keperawatan. Jakarta Salemba Medika

Hidayat, Aziz Alimul. 2008. Ilmu Kesehatan Anak untuk Pendidikan Kebidanan. Jakarta : Salemba Medika

Hidayat, Aziz Alimul. 2011. Ilmu Kesehatan Anak untuk Pendidikan Kebidanan. Jakarta : Salemba Medika

Hidayat. 2009. Metode Penelitian Kebidanan dan Teknik Analisa Data. Surabaya

Hurlock. 2013. Perkembangan Anak. Jakarta : Erlangga

Judarwanto, Widodo. 2012. Perkembangan anak. Dari http:// medicastore.com. Diakses tanggal 15 April 2012

Kementrian Kesehatan Republik Indonesia. 2010. Pedoman Pelaksanaan Stimulasi, deteksi dan Intervensi Dini Tumbuh Kembang Anak di Tingkat Pelayanan Kesehatan Dasar. Jakarta

Kepmenkes. Permenkes. 2004. Pedoman Persyaratan Kesehatan Pelayanan Sehat Pakai Air (SPA). Jakarta

Mansyur. 2005. Pendidikan Anak Usia Dini. Yogyakarta : Pustaka Pelajar

Maryunani, Anik. 2010. Ilmu Kesehatan Anak dalam Kebidanan. Jakarta : Trans Info Media
Notoatmodjo, Soekidjo. 2012. Metodologi Penelitian kesehatan. Jakarta : Rineka Cipta

Roesli, U. 2010. Pedoman Pijat Bayi. PT Trubus Agriwidya : Jakarta

Setiawan, Ari dan Saryono. 2011. Metodologi Penelitian Kesehatan. Yogyakarta : Nuha Medika

Siska. 2009. Pijat Bayi. Jakarta : Puspa Swara

Sugiyono. 2010. Statistika Untuk Penelitian. Bandung : Alfabeta

Soedjatmiko. Pentingnya Stimulasi Dini Untuk Merangsang Perkembangan Bayi dan Balita Terutama pada Bayi Resiko Tinggi. Sari Pediatri. Vol 8

Soetjiningsih. 2014. Tumbuh Kembang Anak. Jakarta : EGC

Yahya, N. 2011. Spa Bayi \& Anak. Dipl. CIBTAC. Solo 